\title{
Microorganisms Associated with Vegetable Oil Polluted Soil
}

\author{
Bukola Margaret Popoola, A. A. Onilude \\ Department of Microbiology, University of Ibadan, Ibadan, Nigeria \\ Email: bukolamargaret@yahoo.com
}

How to cite this paper: Popoola, B.M. and Onilude, A.A. (2017) Microorganisms Associated with Vegetable Oil Polluted Soil. Advances in Microbiology, 7, 377-386. https://doi.org/10.4236/aim.2017.75031

Received: April 14, 2017

Accepted: May 20, 2017

Published: May 23, 2017

Copyright $\odot 2017$ by authors and Scientific Research Publishing Inc. This work is licensed under the Creative Commons Attribution International License (CC BY 4.0).

http://creativecommons.org/licenses/by/4.0/

\begin{abstract}
Vegetable oil Spills are becoming frequent and are potentially more challenging than petroleum hydrocarbon spills. Microbial lipases occupy a place of prominence among biocatalysts are often used for remediation of vegetable oil-polluted sites. This work was carried out to isolate microorganisms from oil-polluted sites and screen them for their lipolytic activity. Microorganisms were isolated from eight experimental soil samples contaminated with different types of vegetable oil, soil from an oil mill in Ibadan, and normal uncontaminated soil as a control. The isolates were characterized, identified and those common to at least one of the experimental sites and oil mill sites were screened for their lipolytic activity. Data obtained were analysed using Duncan Multiple Range Test. Seventy three microorganisms were isolated from the polluted soil and identified as species of Bacillus (16), Pseudomonas (12), Flavobacterium (6), Alcaligenes (2), Proteus (3), Micrococcus (1), Aspergillus (9), Penicillium (6), Saccharomyces (4), Geotrichum (1), Kluveromyces (1). Bacillus subtilis, Bacillus licheniformic, Pseudomonas cepacia, Pseudomonas fluorescens, Flavobacterium sp., Alcaligenes sp. and Candida parapsilosis which were common to at least one of the experimental site and oil mill site were preliminarily screened for lipolytic activity and all nine confirmed by presence of halos around the colonies. These screened organisms have potential for the degradation of fatty waste. They could therefore be employed in environmental clean-up of vegetable oil spill site.
\end{abstract}

\section{Keywords}

Microorganisms, Degradation, Vegetable Oil Spill, Lipolytic Activity

\section{Introduction}

Vegetable oils are oil extractions from plants and fruits such as palm nut, sunflower, soybean, coconut, rapeseed, canola, olive, castor and corn [1]. 
Like mineral oils, vegetable oils can vary significantly and when released to the marine environment for instance will behave differently according to their individual characteristics. These characteristics depend on factors at the time of cultivation of the feed stock for example, climate; degree of processing; type and specific nature of the oil, sea state and weather conditions at the time of the spill. In many cases, the influence of vegetable oil characteristics on its behaviour in the environment is not well-studied or understood. Consequently, the behavior and fate of specific vegetable oils is somewhat more difficult to predict than that of mineral oils.

Vegetable oils comprised primarily of triacylglycerols or fatty acids, which, in their fresh state, may be broken down by bacteria, fungi and yeast. This breakdown is as a result of lipases, a class of hydrolases primarily responsible for hydrolysis of acylglycerides. Many microorganisms such as bacteria, yeasts, molds and a few protozoa are known to secrete lipases for the digestion of lipid materials [2] [3] [4].

These organisms produce veritable development sources of lipases with different enzymological properties and specificities but molds are known to be more potent lipase producer [5].

Lipase producers have been isolated mainly from soil or spoiled food material that contains vegetable oil. Lipase production from a variety of bacteria, fungi and actinomycetes has been reported in several works [6] [7]. Vegetable oil spills are becoming more common and are potentially more challenging than hydrocarbon spills [8]. One spill can spread fast between bodies of water and the land, coming in contact with humans, plants and animals.

Microorganisms are therefore useful hi protecting the environment. It is significant to isolate microbes of high potential for the biodegradation of vegetable oil. Therefore, this study was undertaken to isolate, identify, characterize and screen microorganisms from vegetable oil contaminated soil samples.

\section{Materials and Methods}

\subsection{Sample Collection}

Soil samples were collected from a vegetable oil factory: oil mills, challenge area of $7^{\circ} 21^{\prime \prime} \mathrm{N} 3^{\circ} 53^{\prime \prime} \mathrm{E}$ Ibadan during the raining season; and soil from the nursery section of department of Botany university of Ibadan thoroughly mixed with eight different types of edible oil purchased at different retail markets in Ibadan metropolis.

Hundred milliliters and $200 \mathrm{mls}$ of each of the oil samples were mixed thoroughly with $2 \mathrm{~kg}$ of the soil sample collected from the plant nursery of the Department of Botany. Two kilograms of the uncontaminated soil was collected also at the same site. These various samples were placed in bowls for 2 months.

\subsection{Isolation and Identification of Organisms}

Isolation of all the isolates was carried out using the method of [9]. $1 \mathrm{ml}$ inoculum was aseptically transferred into a sterile petridish and pour-plated with the 
appropriate agar medium: Nutrient agar for bacterial isolation and potato dextrose agar for fungiisolation. The plates were incubated at room temperature $27^{\circ} \mathrm{C} \pm 2^{\circ} \mathrm{C}$ ) for 24 hours in the case of bacterial isolates, while fungal isolates were incubated for 3 to 5 days. Morphological appearances of the inoculated plates were observed and distinct colonies were sub-cultured to obtain pure isolates which were then maintained on nutrient agar and potato dextrose agar slants for bacterial and fungal isolates respectively and preserved at $4^{\circ} \mathrm{C}$.

Bacterial isolates were identified using morphological procedures and biochemical tests, with reference to Bergey's Manual of Systematic Bacteriology [10].

The isolated fungi were identified according to their micro-morphology, as well as colour and morphology of sporulating structures, reference was made to compendium of soil fungi. The Yeasts were identified and confirmed using API 20 Aux kit.

\subsection{Preliminary Screening for Lipolytic Activity}

Lipolytic activities of the test isolates were initially screened for on olive oil agar medium. The screening was carried out by a modified method of [11]. The medium consisted ( $\mathrm{g} / \mathrm{L}$ ) of $\mathrm{KH}_{2} \mathrm{PO}_{4}, 7.584 ; \mathrm{K}_{2} \mathrm{HPO}_{4}, 0.80 ; \mathrm{MgSO}_{4} \cdot 7 \mathrm{H}_{2} \mathrm{O}, 0.80 ; \mathrm{CaCl}_{2}$, 0.16; (NH4) $)_{2} \cdot \mathrm{NO}_{3}, 0.80 ; \mathrm{FeSO}, 0.16$; Agar, 20; Olive oil 2\%, $\mathrm{pH}$ was maintained at 7.0. $1 \mathrm{ml}$ of the inoculum of each isolate was introduced into $10 \mathrm{ml}$ of the sterilized medium in an Erlenmeyer flask and pour-plated, incubation was at room temperature $\left(27^{\circ} \mathrm{C} \pm 2^{\circ} \mathrm{C}\right)$ for 7 days. After incubation the olive oil agar plates were observed for visible growth, signifying hydrolysis.

In another instance, the isolates were further confirmed for lipolytic activity using a medium containing, $15 \mathrm{~g}$ peptone, $0.1 \mathrm{~g} \mathrm{Cacl}_{2}, 5 \mathrm{~g} \mathrm{NaCl}$ all weighed and dissolved in sequence by addition of $800 \mathrm{ml}$ of water and the $\mathrm{pH}$ adjusted to 7.5 with $\mathrm{NaOH}$. Thereafter, $15 \mathrm{~g}$ of agar was added. The volume was made up to 1 liter. The mixture was sterilized by autoclaving for 15 minutes at $121^{\circ} \mathrm{C}$. One percent $(\mathrm{V} / \mathrm{V})$ high refined olive oil purified by membrane filtration and $5 \mathrm{~g}$ Aniline blue dissolved in distilled water and filter-sterilized.

\section{Result and Discussion}

Thirty-four bacterial isolates were obtained from the soil sample in the bowls contaminated with different types of edible oil. Thirty fungal isolates and yeasts inclusive were also obtained, as shown on Table 1 and Table 2. From the oilmill, nine bacterial and three fungal isolates were obtained. The bacterial isolates were identified as Bacillus subtilis, Pseudomonas cepacia, Bacillus licheniformis, Pseudomonas fluorescens, Alcaligenes sp. and flavobacterium sp. The three fungal isolates were identified as Geotrichum candidum, Penicillium atrovenetum and Candida parapsilosis. All these are as shown on Table 3 and Table 4 in their frequency of occurrence. Bacteria were the predominant organisms isolated from the samples. This is in agreement with the work [12]. 
Table 1. Organisms (bacteria) isolated from soil samples contaminated with different types of vegetable oil.

\begin{tabular}{|c|c|}
\hline Isolate Code/Source of Isolation & Organisms Isolated \\
\hline $\mathrm{GN}_{1}$ (Groundnut oil) & Bacillus licheniformis \\
\hline $\mathrm{GN}_{2}$ & Bacillus subtilis \\
\hline $\mathrm{GN}_{3}$ & Bacillus pumilus \\
\hline $\mathrm{GN}_{4}$ & Flavobacterium sp. \\
\hline $\mathrm{GN}_{5}$ & Micrococcus luteus \\
\hline $\mathrm{OO}_{1}$ (Olive oil) & Bacillus licheniformis \\
\hline $\mathrm{OO}_{2}$ & Flavobacterium sp. \\
\hline $\mathrm{OO}_{3}$ & Alcaligenes sp. \\
\hline $\mathrm{OO}_{4}$ & Pseudomonas putida \\
\hline $\mathrm{OO}_{5}$ & Bacillus alvei \\
\hline $\mathrm{OO}_{6}$ & Pseudomonas fluorescens \\
\hline $\mathrm{OO}_{7}$ & Bacillus megaterium \\
\hline $\mathrm{OO}_{8}$ & Pseudomonas cepacia \\
\hline $\mathrm{CS}_{1}$ (Cottonseed oil) & Bacillus alvei \\
\hline $\mathrm{CS}_{2}$ & Bacillus licheniformis \\
\hline $\mathrm{CS}_{3}$ & Pseudomonas putida \\
\hline $\mathrm{CS}_{4}$ & Flavobacterium sp. \\
\hline $\mathrm{SF}_{1}$ (Sunflower oil) & Flavobacterium sp. \\
\hline $\mathrm{SF}_{2}$ & Pseudomonas putida \\
\hline $\mathrm{SF}_{3}$ & Pseudomonas cepacia \\
\hline $\mathrm{SF}_{4}$ & Bacillus alvei \\
\hline $\mathrm{PO}_{1}$ (Palm oil) & Bacillus alvei \\
\hline $\mathrm{PO}_{2}$ & Proteus mirabilis \\
\hline $\mathrm{PO}_{3}$ & Bacillus subtilis \\
\hline $\mathrm{SO}_{1}$ (Soya oil) & Pseudomonas putida \\
\hline $\mathrm{SO}_{2}$ & Pseudomonas flurescense \\
\hline $\mathrm{SO}_{3}$ & Pseudomonas fluorescens \\
\hline $\mathrm{PK}_{1}$ (Palmkernel oil) & Flavobacterium sp. \\
\hline $\mathrm{PK}_{2}$ & Proteus vulgaris \\
\hline $\mathrm{PK}_{3}$ & Pseudomonas putida \\
\hline $\mathrm{PK}_{4}$ & Bacillus licheniformis \\
\hline $\mathrm{VO}_{1}$ Vegetable oil (king) & Bacillus licheniformis \\
\hline $\mathrm{VO}_{2}$ & Bacillus subtilis \\
\hline $\mathrm{VO}_{3}$ & Pseudomonas putida \\
\hline
\end{tabular}


Table 2. Organisms (Fungi) isolated from soil sample contaminated with different types of vegetable oil.

\begin{tabular}{|c|c|}
\hline Isolate Code/Source of Isolation & Organisms Isolated \\
\hline $\mathrm{GN}_{1}$ (Groundnut oil) & Saccharomyces cerevisae \\
\hline $\mathrm{GN}_{2}$ & Mucor meihei \\
\hline $\mathrm{GN}_{3}$ & Aspergillus niger \\
\hline $\mathrm{OO}_{1}$ (Olive oil) & Penicillium expansum \\
\hline $\mathrm{OO}_{2}$ & Aspergillus niger \\
\hline $\mathrm{OO}_{3}$ & Rhizopus oryzae \\
\hline $\mathrm{CS}_{1}$ (Cottonseed oil) & Mucor racemosus \\
\hline $\mathrm{CS}_{2}$ & Saccharomyces rouxii \\
\hline $\mathrm{CS}_{3}$ & Aspergillus terreus \\
\hline $\mathrm{CS}_{4}$ & Penicillium funiculosum \\
\hline $\mathrm{SF}_{1}$ (Sunflower oil) & Saccharomyces rouxii \\
\hline $\mathrm{SF}_{2}$ & Aspergillus niger \\
\hline $\mathrm{SF}_{3}$ & Penicillium herquei \\
\hline $\mathrm{PO}_{1}$ (Palm oil) & Candida valida \\
\hline $\mathrm{PO}_{2}$ & Mucor racemosus \\
\hline $\mathrm{PO}_{3}$ & Candida parapsilosis \\
\hline $\mathrm{SO}_{1}$ (Soya oil) & Aspergillus niger \\
\hline $\mathrm{SO}_{2}$ & Penicillium herquei \\
\hline $\mathrm{SO}_{3}$ & Rhizopus oryzae \\
\hline $\mathrm{SO}_{4}$ & Saccharomyces rouxii \\
\hline $\mathrm{SO}_{5}$ & Streptomyces nitrosporeus \\
\hline $\mathrm{PK}_{1}$ (Palmkernel oil) & Penicillium expansum \\
\hline $\mathrm{PK}_{2}$ & Aspergillus terreus \\
\hline $\mathrm{PK}_{3}$ & Kluyveromyces africanus \\
\hline $\mathrm{PK}_{4}$ & Aspergillus niger \\
\hline $\mathrm{PK}_{5}$ & Streptomyces nitrosporeus \\
\hline $\mathrm{VO}_{1}$ (Vegetable oil) & Aspergillus niger \\
\hline $\mathrm{VO}_{2}$ & Mucor meihei \\
\hline $\mathrm{VO}_{3}$ & Aspergillus terreus \\
\hline $\mathrm{VO}_{4}$ & Aspergillus niger \\
\hline
\end{tabular}


Table 3. Frequency of occurrence of bacterial isolates from both artificially-contaminated and oil mill site soil samples.

\begin{tabular}{ccc}
\hline & \multicolumn{2}{c}{ Type of soil/Frequency of occurrence } \\
\hline Isolate Name & Artificially contaminated soil & Contaminated soil from oil mill site \\
\hline Bacillus licheniformis & $5(14.7)$ & $1(11.1)$ \\
Bacillus subtilis & $3(8.8)$ & $2(22.2)$ \\
Bacillus pumilus & $1(2.9)$ & - - \\
Flavobacterium sp. & $5(14.7)$ & $1(11.1)$ \\
Micrococcus luteus & $1(2.9)$ & - - \\
Alcaligenssp & $2(5.9)$ & $1(11.1)$ \\
Pseudomonas putida & $5(14.7)$ & - - \\
Bacillus alvei & $4(11.8)$ & - \\
Pseudomonas fluorescens & $2(5.9)$ & $2(22.2)$ \\
Bacillus megaterium & $1(2.9)$ & - \\
Pseudomonas cepacia & $2(5.9)$ & - \\
Proteus mirabilis & $1(2.9)$ & - \\
Proteus vulgaris & $2(5.9)$ & $9(100)$ \\
Total & $34(100)$ &
\end{tabular}

Values in parentheses represent percentage of occurrence.

Table 4. Frequency of occurrence of fungal and yeast isolates from both artificially-contaminated and oil mill site soil samples.

\begin{tabular}{ccc}
\hline & Type of soil/Frequency of occurrence \\
\hline Isolate & Artificially-contaminated & Contaminated soil from oil mill site \\
\hline Saccharomyces cerevisae & $1(3.3)$ & - \\
Aspergillus niger & $7(23.3)$ & - \\
Penicillium expansum & $2(6.7)$ & - \\
Rhizopus oryzae & $2(6.7)$ & - \\
Aspergillus terreus & $3(6.7)$ & - \\
Penicillium funiculosum & $1(3.3)$ & $1(33.3)$ \\
Penicillium herquei & $2(6.7)$ & - \\
Penicillium atrovenetum & - & - \\
Mucor meihei & $2(6.7)$ & - \\
Mucor racemosus & $2(6.7)$ & - \\
Saccharomyces rouxii & $3(10)$ & - \\
Candida valida & $1(3.3)$ & - \\
Candida parapsilosis & $1(3.3)$ & $(33.3)$ \\
Streptomyces nitrosporeus & $2(6.7)$ & - \\
Kluyveromyces africanus & $1(3.3)$ & - \\
Geotrichum candidum & $30(100)$ & - \\
Total & - & - \\
\hline
\end{tabular}

Values in parentheses represent percentage of occurrence. 
Several researchers have isolated various microbial species from oil contaminated soils [12]-[17].

Table 5 shows the total heterotrophic count for both bacteria and fungi isolated from the bowls contaminated with different types of edible oil. There was notable significant difference among all the different edible oil used to purposely contaminate the soil at both $100 \mathrm{ml}$ and $200 \mathrm{ml}$. Indeed, the total heterotrophic count for bacteria from palmkernel oil significantly was higher than others. However total heterotrophic count for fungi purposely contaminated with 100 and $200 \mathrm{ml}$ of vegetable oil and palm oil respectively were significantly higher than others. Table 6 shows total heterotrophic count for isolates from oil mill contaminated site.

Different screening strategies have been proposed for the determination of lipase activity, assays using agar plates are highly recommended, because it is an easier method with lower cost [18]. Assay using agar plates are performed due to the fact that activities for lipases are hard to determine because of the water-soluble enzyme acting on substrates which are insoluble [19].

For this study only isolates common to both purposely contaminated soil and oil mill soil were screened for lipase production. Table 7 shows the result of the screening experiment for qualitative production of lipase by the selected isolates using olive oil agar medium. Results show that these selected organisms all showed lipolytic activity as a result of the whitish halos (precipitate) around the lipase producing colonies seen on the agar plates.

Table 5. Total microbial count in soil samples contaminated with different types of edible oil.

\begin{tabular}{ccccc}
\hline \multirow{2}{*}{ Sample } & \multicolumn{3}{c}{ Microbial group/volume of edible oil/count $\left(\log _{10} \mathrm{cfu} / \mathrm{ml}\right)$} \\
\cline { 2 - 5 } & \multicolumn{1}{c}{ Heterotrophic bacterial count } & \multicolumn{2}{c}{ Heterotrophic fungal count } \\
\hline Description & $100 \mathrm{ml}$ & $200 \mathrm{ml}$ & $100 \mathrm{ml}$ & $200 \mathrm{ml}$ \\
\hline Groundnut oil & $4.491^{\mathrm{g}}$ & $3.8451^{\mathrm{f}}$ & $4.6812^{\mathrm{c}}$ & $3.0000^{\mathrm{g}}$ \\
Olive oil & $5.2021^{\mathrm{d}}$ & $5.0792^{\mathrm{b}}$ & $3.7782^{\mathrm{e}}$ & $3.3010^{\mathrm{e}}$ \\
Soya oil & $5.1761^{\mathrm{e}}$ & $0.0000^{\mathrm{h}}$ & $4.6021^{\mathrm{d}}$ & $3.2788^{\mathrm{e}}$ \\
Palm kernel oil & $6.3222^{\mathrm{a}}$ & $6.1461^{\mathrm{a}}$ & $4.2788^{\mathrm{e}}$ & $4.1461^{\mathrm{b}}$ \\
Palm oil & $4.5798^{\mathrm{f}}$ & $4.2305^{\mathrm{e}}$ & $4.7324^{\mathrm{b}}$ & $4.2305^{\mathrm{a}}$ \\
Cottonseed oil & $5.9638^{\mathrm{b}}$ & $4.8692^{\mathrm{c}}$ & $4.8633^{\mathrm{a}}$ & $3.6021^{\mathrm{d}}$ \\
Vegetable oil & $5.3424^{\mathrm{c}}$ & $4.3802^{\mathrm{d}}$ & $4.8865^{\mathrm{a}}$ & $4.0000^{\mathrm{c}}$ \\
Sunflower oil & $5.3424^{\mathrm{c}}$ & $2.0000^{\mathrm{g}}$ & $3.7782^{\mathrm{e}}$ & $3.3010^{\mathrm{e}}$ \\
\hline
\end{tabular}

Values with different superscripts are significantly different $(P \leq 0.05)$ with respect to Duncan's Multiple Range Test.

Table 6. Total heterotrophic count of isolates of soil samples from oil mill contaminated site.

\begin{tabular}{cc}
\hline Microbial group & Total count $\left(\log _{10} \mathrm{cfu} / \mathrm{ml}\right)$ \\
\hline Bacteria & 5.44 \\
Fungi & 5.74 \\
\hline
\end{tabular}


Table 7. Results of the qualitative screening of isolates for lipolytic activity.

\begin{tabular}{cc}
\hline Isolates & Lipolytic activity \\
\hline Bacillus subtilis & + \\
Pseudomonas cepacia & + \\
Bacillus licheniformis & + \\
Pseudomonas fluorescens & + \\
Alcaligenes sp. & + \\
Flavobacterium sp. & + \\
Candida parapsilosis & +
\end{tabular}

Key: + Positive Presence of halos around the colonies.

The microbial isolates in this study proved capable of lipase production. Indeed, lipolyticactivity has been observed for pure cultures of all the microbial genera isolated in this study [20] [21] [22] [23].

The formation of opaque zones around the colonies of the selected isolates is an indication of lipase production by the organisms [24]. Literatures have confirmed that under certain conditions, it is possible to isolate bacterial strains capable of degrading lipids by using selective medium containing required inducers. Those lipid-degrading bacteria often produce extracellular lipase enzymes, where these enzymes are generally inducible in the presence of different inducers such as olive oil, palm oil, oleic acid and Tween 80 [25] [26] [27]. [28] also used a selective medium, which contained Tween 80 and olive oil to screen through the appearances of clearing zones for the bacterial strain Pseudomonas sp.

\section{Conclusion}

This study revealed that 73 microorganisms in all belonging to different genera were isolated from different sources and all proven to be capable of lipase production. Hence this gives opportunity to explore or investigate these microbial lipases which are an important group of biotechnological valuable enzymes and could be better explored for fatty waste degradation.

\section{References}

[1] http://www.itopf.com/

[2] Singh, A.K. and Mukhopadhyay, M. (2012) Overview of Fungal Lipase: A Review. Applied Biochemistry and Biotechnology, 166, 186-520. https://doi.org/10.1007/s12010-011-9444-3

[3] Nagarajan, S. (2012) New Tools for Exploring "Old Friends-Microbial Lipases". Applied Biochemistry and Biotechnology, 168, 1163-1196. https://doi.org/10.1007/s12010-012-9849-7

[4] Abrunhosa, L., Oliveira, F., Dantas, D., Goncalves, C. and Belo, I. (2013) Lipase Production by Aspergillus ibericus Using Olive Mill Waste Water. Bioprocess and Biosystem Engineering, 36, 285-291. https://doi.org/10.1007/s00449-012-0783-4

[5] Choo, D., Kurihara, T., Suzuku, T., Soda, K. and Esaki, N. (1998) A Cold-Adapted Lipase of an Alaskan Psychrotroph, Pseudomonas sp. Strain B11-1: Gene Cloning 
and Enzyme Purification and Characterization. Applied and Environmental Microbiology, 64, 486-491.

[6] Sztajer, H., Maliszewska, I. and Weiczorek, J. (1988) Production of Exogenous Lipases by Bacteria, Fungi, and Actinomycetes. Enzyme and Microbial Technology, 10, 492-497.

[7] Kulkarni, N. and Gadre, R.V. (2002) Production and Properties of an Alkaline, Thermophilic Lipase from Pseudomonas fluorescens NS2W. Journal of Industrial Microbiology and Biotechnology, 28, 344-348.

[8] www.epa.gov/oilspill

[9] Harrigan, W.F. and McCance, M.E. (1976) Laboratory Methods in Food and Dairy Microbiology. Academic Press Inc. Limited, London.

[10] Sneath, P.H.A. (1986) Bergey's Manual of Systematic Bacteriology. Vol. 2, The Williams and Wilkins Co., Baltimore.

[11] Gogoi, B.K., Dutta, N.N., Goswani, P. and Krishna, M.T.R. (2003) A Case Study of Bioremediation of Petroleum-Hydrocarbon Contaminated Soil at Crude Oil Spill Site. Advances in Environmental Research, 7, 767-782.

[12] Haliru, M. and Bukola, C.A. (2012) Screening of Microorganisms Isolated from Different Environmental Samples for Extracellular Lipase Production. AU J.T., 15, 179-186.

[13] Gupta, R., Gupta, N.J. and Rathi, P. (2004) Bacterial Lipase: An Overview of Production, Purification and Biochemical Properties. Applied Microbiology and Biotechnology, 64, 763-781. https://doi.org/10.1007/s00253-004-1568-8

[14] D’Annibale, A., Sermanni, G.G. and Federici, F. (2006) Olive-Mill Wastewaters a Promising Substrate for Microbial Lipase Production. Bioresource Technology, 97, 1823-1833.

[15] Riaz, M., Shah, A.A., Hammed, A. and Hasan, F. (2010) Characterization of Lipase Produced by Bacillus sp. FHS in Immobilized and Free State. Annals of Microbiology, 60, 169-175. https://doi.org/10.1007/s13213-009-0012-9

[16] Nwuche, C.O. and Ogbonna, J.C. (2011) Isolation of Lipase Producing Fungi from Palm Oil Mill Effluent (POME) Dump Sites at Nsukka. Brazilian Archives of Biology and Technology, 54, 113-116. https://doi.org/10.1590/S1516-89132011000100015

[17] Thota, P., Bhogavalli, P.K., Vallem, P.R. and Screerangam, V. (2012) Biochemical Characterization of an Extracellular Lipase from New Strain of Rhizopus sp. Isolated from Oil Contaminated Soil. International Journal of Plant Animal and Environmental Sciences, 2, 41-45.

[18] Gopinath, S.C.B., Anubu, P., Lakshmipnya, T. and Hilda, A. (2013) Strategies to Characterize Fungal Lipases for Applications in Medicine and Dairy Industry. BioMed Research International, 2013, Article ID: 154549.

[19] Kanchana, R., Muraleedharan, U.D. and Raghukumar, S. (2011) AAlkaline Lipase Activity from the Marine Protists, Thraustochytrids. World Journal of Microbiology and Biotechnology, 27, 2125-2131. https://doi.org/10.1007/s11274-011-0676-8

[20] Sharma Chander, K. and Kanwar Shamsher, S. (2001) Purification of a Novel Thermophilic Lipase from Bacillus licheniformis MTCC-10498. ISCA Journal of Biological Sciences, 1, 43-48.

[21] Saxena, R.K., Sheoran, A., Giri, B. and Davidson, W.S. (2002) Purification Strategies for Microbial Lipases. Journal of Microbiological Methods, 52, 1-18.

[22] Chakraborty, K. and Raj, K.R. (2008) An Extra-Cellular Alkaline Metallolipase from Bacillus licheniformis MTCC 6824: Purification and Biochemical Characterization. Food Chemistry, 109, 727-736. 
[23] Sharma, R.K., Jethani, B., Raipuria, M. and Jain, H. (2011) Antipyretic Activity of Aqueous and Alcoholic Extracts of Nonion Yeast Induced Pyrexia in Rats. International Journal of Pharmaceutical Sciences and Research, 2, 1850-1854.

[24] Rohit, S., Yusuf, C. and Uttam, C.B. (2001) Production, Purification, Characterization and Applications of Lipases. Biotechnology Advances, 19, 627-662.

[25] Shabtai, Y. (1991) Isolation and Characterization of a Lipolytic Bacterium Capable of Growing in a Low-Water Content Oil Water-Emulsion. Applied and Environmental Microbiology, 57, 1740-1745.

[26] Shabtai, Y.A. and Daya-Mishire, N. (1992) Production, Purification and Properties of Lipase from a Bacterium Pseudomonas aeruginosa Y57. Capaolie of Growing in Water Restricted Environment. Applied and Environmental Microbiology, 58, 174180.

[27] Sigurgisledottir, S., Sonraodottir, M., Jonsson, A., Kristjarsson, J.K. and Mattheasson, E. (1993) Lipase Activity of Thermophilic Bacteria from Icelandic Hot Springs. Biotechnology Letters, 15, 361-366. https://doi.org/10.1007/BF00128277

[28] Loo, J.L., Lai, O.M., Long, K. and Ghazali, H.M. (2006) Identification and Characterization of a Locally Isolated Lipolytic Microfungus Geotrichum candidium. Malays Journal of Microbiology, 2, 22-29.

Submit or recommend next manuscript to SCIRP and we will provide best service for you:

Accepting pre-submission inquiries through Email, Facebook, LinkedIn, Twitter, etc. A wide selection of journals (inclusive of 9 subjects, more than 200 journals) Providing 24-hour high-quality service

User-friendly online submission system

Fair and swift peer-review system

Efficient typesetting and proofreading procedure

Display of the result of downloads and visits, as well as the number of cited articles Maximum dissemination of your research work

Submit your manuscript at: http://papersubmission.scirp.org/

Or contact aim@scirp.org 